\title{
Fieldwork and Ethnographic Data: Hungarian Ethnological Scholarship
}

\author{
Foreword
}

\author{
Csaba Mészáros - Gábor Vargyas \\ Institute of Ethnology, RCH, Hungarian Academy of Sciences, Budapest
}

The history of fieldwork methodology can be traced alongside and in accordance with the thematic evolution of the fields of both anthropology and that of, ethnography. In endeavoring to systematize the realms of anthropological inquiry, the discipline has, from the mid- $18^{\text {th }}$ century onwards, reflected on the diversity of ethnographic data while assembling manuals and guides for fellow ethnologists. The impetus behind this process was to begin to define methods of collecting empirical data in order to demarcate the structural framework of the academic domain of ethnological scholarship (BUCHER 2002; VermeUlen 2015). The development of the disciplines of anthropology and ethnology were marked by a series of publications that fixated on matters of fieldwork and data collection. Perhaps the most influential of these sources was the well-known volume entitled, "Notes and Queries on Anthropology" which was reviewed and edited several times between the years 1874 and 1951 (URRY 1972). In specific, fieldwork methodology outlines the means and ways of confronting empirical data and unfamiliar worlds. It also situates and delineates the domain of anthropological inquiry (LANGHAM 1981). Therefore, studies on fieldwork techniques do not merely focus on methodology, but also frequently touch on fundamental issues that surround and breach beyond the discipline as a whole.

Anthropologists and ethnographers regularly reflect on and reassess their fieldwork methodologies for at least two main reasons. Firstly, as with other disciplines, those invested in the field will periodically clarify and specify individual and group stances with regards to the collection and assemblage of empirical data. They do so in order to theorize and conceptualize the link between ethnographic data and that of theoretical academic concepts. The development of theories in anthropology has demanded the regular reassessment of methods in the field, and has resultantly given way to the ever-increasing technicization of ethnographic fieldwork methods. Secondly, the sociocultural environment of anthropological inquiry is constantly in motion and is thus, subject to change. In today's climate, researchers enter the field and adapt to "studied" communities on radically different terms, than say 30 years ago, or perhaps even in the days of Malinowksi, when methods of stationary fieldwork and participatory observation were laid down at the dawn of the $20^{\text {th }}$ century. 
Unlike international anthropological scholarship, Hungarian ethnographers have rarely problematized fieldwork methodology and the empirical basis of ethnographic data. Apart from of an introductory course book (BöDI 1982) and a heated debate in the leading journal of Hungarian ethnography in 1954 (VAJDA 1954; BoDroGI 1954; VARGYAS 1954), Hungarian ethnographers have not focused at great length on researching the epistemological status of ethnographic data. Instead of scrutinizing methodological and epistemological questions, Hungarian ethnographers have published a considerable corpus of manuals and guides for fieldworkers collecting ethnographic data. In these guides, authors solely focused on the ethnographic material, excluding questions regarding the relationship between interlocutors/informants and that of researchers (BARABÁS 1959). Rather than studying the specificities and ethical concerns of the intersubjective reality created by fieldwork situation, they found empirical reality unproblematic. Ethnographic data was simply "out there" passively waiting for ethnographers to find and "pick up". Despite the fact that the last few decades have been witness to the emergence of pioneering studies on fieldwork methodology in Hungarian (Boglár 2004; BorsánYi 1988) no comprehensive volume aimed at openly discussing the problems of fieldwork methodology has been accounted for to date, until this point. As an aside, it is of note that the emergence of studies on fieldwork methodology is in accordance with the institutionalization of the field of anthropology in Hungary.

In order to stimulate discourse on fieldwork methodology in Hungarian ethnography and anthropology, our editors organized two separate yet interrelated conferences on fieldwork. They organized the first event from September 22-23 $3^{\text {rd }}$ in 2016 inviting researchers from the Institute of Ethnology (Hungarian Academy of Sciences, Research Centre for the Humanities) to exchange ideas and personal experiences on fieldwork methods. The 2016 issue of the Institute's yearbook (Ethno-Lore) published papers presented at the first conference. Based on the great interest encountered during the organization of the first conference, as well as the success of the aforementioned edition of the yearbook, we decided to organize a second conference, in order to address a broader audience of ethnographers. This conference took place from the $10-11^{\text {th }}$ of February in 2017 at the Hungarian Academy. It assembled and summoned the most important ateliers of Hungarian ethnography and anthropology. During the course of the closing round table discussion of the event, participants agreed that a considerable number of the more than 40 papers (presented at the two conferences) should also be published in English, in order to provide insight on the current state of fieldwork methodology in Hungarian ethnography for non-Hungarian readers. Thus, this present volume of Acta Ethnographica Hungarica accounts for the assiduously selected, yet ever representative selection of papers presented during the course of the two conferences mentioned above.

In selecting these papers, we aimed at problematizing first the present circumstances and conditions of fieldwork, and secondly it was our incentive to summarize the history of the methods of data collection in Hungarian ethnography. In addition, we were adamant in providing a balanced view of personal accounts, as well as epistemological and methodological issues. Lastly, by choosing a roughly even number of papers from the varying subfields of folkloristics, ethnology, anthropology and ethnography we intended to provide readers with impressions and samples of the most integral domains of our scholarly discipline. 
Mihály Sárkány begins the cycle of papers in the first article of this current issue in which he argues, that it is the field and therefore, the encountered reality rather than the abstract method utilized that should dominate ethnographies. Thus, dissimilar fields demand dissimilar research methods. A good example of this is Balázs Balogh's article, who describes how the socio-cultural context of Hungarians living in the United States of America affected the fieldwork methods he applied during his stay on site. In recalling a personal story from his fieldwork in Vietnam, Gábor Vargyas contends that both the socio-economic and the political context of the field site explored, have the ability to impact the complex decisions of the researcher at hand.

Zoltán Nagy reflects on how the socio-economic state of the research environment may result in personal conflicts. This can also lead to incongruences in research methodology, as exemplified by Csaba Mészáros. In some cases, the public and private pressure on the fieldworker, in conjunction with the secrecy of local communities is so potent, that it hardly allows the anthropologist to collect data (Ildikó Tamás, Gabriella Tuboly-Vincze). This, in turn, compels anthropologists to reassess the basic parameters of fieldwork methodology. As the history of Hungarian folkloristics will show, the reassessment of the basic concepts of fieldwork methodology have oftentimes resulted in ground-breaking works and in paradigm shifts within scholarly discourse (Éva Mikos). Three examples of contemporary ethnographic research exemplify how new methods in anthropology have the unique capacity to fertilize fieldwork methodologies when set against the backdrop of the $21^{\text {st }}$ century. Vilmos Keszeg demonstrates how methods of linguistic anthropology and speech act theory contributed to his fieldwork methodology. Tünde Turai represents the challenges and at times, potential of multi-sited fieldwork methodologies. Lastly, Ágota Ispán displays how complex ethnographic research methods are applicable in researching the social life of nature preserves at the Hungarian-Slovenian border.

We are aware, that these hand-selected articles do not do justice to the vastly comprehensive and coherent corpus of fieldwork methodologies that linger within the multi-colored spectrum that is: Hungarian ethnography. However, we ardently hope to begin to shed new light on some of the pivotal issues currently stimulating contemporary research.

\section{REFERENCES CITED}

BARABÁs, Jenő et al. (eds.)

1959 Magyar Néprajzi Atlasz Gyüjtési Útmutató. [A Guide for the Collectors of Hungarian Ethnographic Atlas]. Budapest: k.n.

Bodrogi, Tibor

1954 A néprajzi anyaggyüjtés módszere és jelentősége (Megjegyzések Vajda László tanulmányához). [Methods of Data Collection in Ethnography (Comments on János Vajda’s Article)]. Ethnographia 65:581-592.

Boglár, Lajos (ed.)

2004 ,Így kutatunk mi...” Az antropológiai terepmunka módszereihez I. ["The Way We Do Research..." On the Fieldwork Methods of Anthropology I.]. Budapest: k.n. (Szimbiózis kötetek 10.). 
BORSÁNYI, László

1988 A megfigyelési technikák az etnológiai terepmunkában [Methods of Observation in Ethnological Fieldwork] Ethnographia 99:53-82.

BöDI, Erzsébet

1982 Bevezetés a magyar néprajzi terepmunka módszertanába [An Introduction to the Methods of Hungarian Ethnographic Fieldwork]. Debrecen: KLTE Néprajz Tanszéke. (Folklór és Ethnográfia 8.).

BuCHER, Gudrun

2002 „Von Beschreibung der Sitten und Gebräuche der Völcker“. Die Instruktionen Gerhard Friedrich Müllers und ihre Bedeutung für die Geschichte der Ethnologie und der Geschichtswissenschaft. Stuttgart: Franz Steiner Verlag.

LANGHAM, Ian

1981 The Building of British Social Anthropology. W.H.R. Rivers and his Cambridge Disciples in The Development of Kinship Studies, 1898-1931. Dordrecht Boston - London: D. Reidel Publishing Company.

URRY, James

1972 "Notes and Queries on Anthropology" and the Development of Field Methods in British Anthropology, 1870-1920. Proceedings of the Royal Anthropological Institute of Great Britain and Ireland, 45-57.

VAJDA, László

1954 A néprajzi anyaggyüjtés módszere és jelentősége [On the Importance and Methods of Data Collection in Ethnography]. Ethnographia 65:1-19.

VARGYAS, Lajos

1954 Vajda László cikkének néhány megállapításához. („A néprajzi anyaggyűjtés módszere és jelentősége" című cikkhez.) [A Few Comments on László Vajda’s Article]. Ethnographia 65:240-244.

VERMEULEN, Han

2015 Before Boas. The Genesis of Ethnography and Ethnology in the German Enlightenment. Lincoln - London: University of Nebraska Press. 